\title{
Introduction
}

\section{New Approaches to Asylum: Reconciling Individual Rights and State Interests}

\author{
Judith Kumin
}

$\mathrm{T}$ The international refugee protection system, which was set up in the wake of the Second World War, has been showing signs of strain for some time now. Some say that it is ill-suited to meet today's challenges, especially those posed by globalization. In a world in which information, capital, goods, and services flow ever more freely across borders, the uncontrolled movement of people is increasingly seen as a threat to the sovereignty of states. Sadly, in an age of global terrorism, it is also seen as a security risk.

When the contemporary refugee regime was established, it was predicated on the willingness of states to relinquish a certain amount of sovereignty, in order to ensure that the basic human rights of a specific category of threatened individuals - refugees - would always be protected. On December 14, 1950, the UN General Assembly adopted Resolution 428 (V) establishing the Office of the UN High Commissioner for Refugees (UNHCR), and giving it a mandate to operate on the territory of sovereign states on behalf of an especially vulnerable group of non-citizens refugees. Just six months later, the 1951 Convention relating to the Status of Refugees was adopted. It established an obligation for states to protect refugees from being returned to situations of danger and to grant them a certain basket of rights normally reserved for citizens.

The willingness of states to agree to this visionary system was in part a recognition that their performance in 1938 at the Evian Conference, and subsequently in turning back Jews trying to escape Nazi Germany, should never be repeated. But it was no doubt also a sign of how little they could imagine the complexity which refugee problems would acquire.

In 1951, refugee problems indeed seemed limited in nature and in scope. As a result, the UNHCR was initially given just a three-year mandate. The agency was tasked with finding new homes for around 1.3 million refugees remain- ing from the Second World War, and would then be dissolved. After that first three-year period, the General Assembly renewed UNHCR's mandate every five years until just a few months ago, in December 2003, it finally lifted altogether the time limitation on UNHCR's mandate, a sobering recognition of the apparent permanence of the world's refugee problems.

Today, countries in both the developing and the developed world are expressing growing dissatisfaction with the international refugee system and are looking for new approaches to refugee problems. The reasons for this dissatisfaction are different in the North and in the South, but the implications are strikingly similar: the rights of refugees and asylum seekers will increasingly be jeopardized, unless ways of addressing states' concerns can be found.

In the developing countries, which host the overwhelming majority of the world's refugees, the threat to asylum arises from the large number of protracted refugee situations ( 70 per cent of the world's refugees have been in exile for more than five years, according to the UNHCR), the absence of durable solutions, the limited capacity of host states to meet refugees' needs, and inadequate burden sharing on the part of the wealthy countries. This is coupled with real or perceived linkages between the presence of refugees and threats to national or regional security, and the rising xenophobia which accompanies all of the above.

In the industrialized world, the strains on the system are caused by irregular migration, the risk it is seen to pose to the security of states and communities, and the abuse or misuse of asylum channels. States lament the high cost of maintaining individual refugee status determination mechanisms, the failure of the many restrictive measures they have crafted to produce the desired results, and the related growth of people smuggling and trafficking. Indus- 
trialized countries also face serious difficulties, both practical and legal, in removing persons they find not to be in need of protection. As in the developing world, these problems combine to generate social tensions, fuel xenophobia, and ultimately undermine public support for the institution of asylum. And these issues are also easily manipulated by politicians for partisan purposes.

In the face of so much dissatisfaction, it seems odd that states would unanimously and unequivocally reaffirm their commitment to the cornerstone of the post-war refugee protection system, the 1951 Convention relating to the Status of Refugees. Yet they did so in December 2001, on the Convention's fiftieth anniversary. If nothing else, this reaffirmation would suggest that states are willing to resolve their dissatisfaction through co-operation rather than confrontation, and through multilateral action rather than through unilateralism.

In reality, however, concern about irregular migration seems to have the upper hand and results in the unilateral implementation of measures which do not incorporate any safeguards for refugees caught up in the immigration control net. Nor does it appear that the wealthy countries' focus on halting irregular migration is matched by a significant shift of resources to the benefit of refugees and their host countries in the South. On February 26, 2004, the UN High Commissioner for Refugees, Ruud Lubbers, announced that asylum applications in the industrialized world had dropped by 20 per cent in 2003 when compared with 2002. Yet the very same day, UNHCR and the World Food Program were forced to launch an urgent appeal for donations, because donor countries had failed to provide the agencies with sufficient resources to supply even the minimum daily caloric ration to refugees in camps in Africa.

This paradox illustrates a risk, namely that the international refugee protection regime may degenerate into a two-tier system. This system would have one standard of behaviour for countries in the developing world, expected to host most of the world's refugees and to keep their doors open, albeit without any guarantee that other countries will share this responsibility. Another standard would apply to the industrialized countries, most of which have the good fortune to be far-removed from refugee-producing areas.

It was in part to tackle this challenge that the UNHCR developed its ambitious two-year Global Consultations on International Protection (2001-2003), and put forward its Agenda for Protection, intended as a kind of road map to strengthen refugee protection in the years ahead. UNHCR's approach to the current challenges is explained in the first article in this issue, authored by two UNHCR officials, Ninette Kelley and Jean-François Durieux. They present UNHCR's "Convention Plus" process, reviewed somewhat skeptically by other authors in this issue, as an effort to bring states and other partners to the negotiating table, to reach concrete agreements to solve specific refugee problems. Although the process is still in its early stages, it remains to be seen whether it will in fact succeed in moving from the theoretical to the particular and, if so, whether it will be able to do so without sacrificing fundamental human rights and refugee protection principles.

A Canadian view of these challenges is provided by Elissa Golberg and Bruce Scoffield, government officials with extensive experience in refugee affairs who are writing in their personal capacity. They urge recognition of the importance of multilateral co-operation to solve refugee problems, and describe some facets of Canada's not inconsiderable contribution to this effort. Still, they warn that states may nonetheless opt for a "lowest common denominator" approach to refugee protection.

An even more sobering perspective is offered by the Hon. Omar Mapuri, Minister of Home Affairs of the United Republic of Tanzania. In remarks made at a panel discussion held during the fifty-fourth session of UNHCR's Executive Committee in late 2003, he appeals for more attention to the situation of refugee-hosting states in the developing world. In addition to advocating for the creation of 'safe havens' within refugee-producing countries, an extremely controversial and widely repudiated idea, he discourages the notion that local settlement of refugees in their host countries in the developing world is a panacea. He also chastises resettlement countries for what he sees as their "cherry-picking" of the best candidates for immigration.

Finding durable solutions for refugees is clearly key to defusing the current crisis, but solutions are scarce. Resettlement - meaning the organized transfer of refugees from a country of first asylum to a third country where permanent settlement is offered - is at present available each year to fewer than 1 per cent of the world's refugees. Repatriation is only possible if conditions in refugees' countries of origin have changed fundamentally. The settlement of refugees in their initial countries of asylum, mostly in the developing world, looks tantalizingly like the most feasible option - notwithstanding Minister Mapuri's warning. Indeed, the UN High Commissioner for Refugees has been actively encouraging governments to integrate the settlement of refugees into their development planning, and has appealed to donor countries to decompartmentalize their development assistance and humanitarian aid, so that refugee-hosting communities can benefit more easily from development monies. But even this eminently sensible approach has not borne much fruit.

The prospect of integrating refugees into their host communities in Uganda is the focus of the article by Sarah 
Dryden-Peterson and Lucy Hovil. They agree that refugee settlement should be placed within the framework of national development plans, but the two case studies they present illustrate that even where there is good will on the part of host communities, there are frustrating barriers to success.

At the other end of the solutions spectrum, Joanne van Selm looks at the potential strategic uses of resettlement. Although resettlement is currently being rehabilitated as a durable solution, she points out that this may be for the wrong reasons. European countries, she says, are all-tootempted to see resettlement as an alternative, rather than a complement, to domestic asylum systems.

Controlling who gets in remains, of course, a central preoccupation of all states, and explains the fundamental tension between globalization and state sovereignty. The next four articles look at this issue from different angles, with security concerns as a constant underlying theme. Benjamin Muller explores the changing nature of "refugee politics," characterized by a number of paradoxes, but most particularly by the paradox between globalization and domestic security concerns. Alexander Betts exposes the content, motivation, and possible consequences of the UK's so-called "New Vision" proposal, and its peculiarly symbiotic relationship with UNHCR's "Convention Plus" initiative. Kinga Janik, writing from a North American perspective, looks at the changing place accorded to refugees in Canadian policy and society, and at the risks posed by the growing negative perception of persons arriving at Canada's borders and asking for protection. And Richard Wazana, in an article initially destined for the previous issue of Refuge devoted to interdiction practices, criticizes Australia's refugee policy and refugee discourse, in the harsh light of the 2001 Tampa incident. Despite UNHCR's consistent appeal for multilateral co-operation to resolve refugee problems, all of these articles show the extent to which states are tempted by (or resort to) unilateralism.

It is chiefly within the European Union that states have made a serious effort to harmonize their approaches to asylum, albeit with rather disappointing results so far. Harold Shepherd reviews efforts to build a common European asylum policy, as called for by the Treaty of Amsterdam. His article was written before the accession of ten new member states on 1 May 2004, and before the last-minute adoption by the European Council of two key asylum instruments, the so-called "Qualification Directive" and the Directive governing asylum procedures, about which the UNHCR has expressed serious concern. In his article, Shepherd appeals for consideration of whether the 1951 Refugee Convention framework is too narrow a basis for the European discussion, urging consideration of the broader protections accorded by human rights law.
Canada, in its new Immigration and Refugee Protection Act, introduced a broadened "Protected Person" status of the type which Shepherd advocates, encompassing protection under the 1951 Refugee Convention, the 1984 Convention against Torture, and under Canada's Charter of Rights and Freedoms (risk to life or risk of cruel and unusual treatment or punishment). This prompts Michael Bossin and Laila Demirdache to ask whether it is "time to re-evaluate the subjective component of the test for persecution in claims for refugee protection"? They urge decision makers to adopt a test which places the emphasis on the objective nature of the risk faced by persons in search of protection.

A turn from the theoretical to the practical is taken by the last two articles in this issue, which serve to remind us that all of this debate about refugee policy ultimately is about people and the lives of individuals. Grant Mitchell and Sara Kirsner paint a compelling picture of the value of a compassionate model of reception support for asylum seekers, one that uses alternatives to detention whenever possible. They explain the enormous utility of community-based counselling in preparing asylum seekers for all immigration outcomes, including compulsory return to their home countries.

Last but by no means least, Claudia Vargas explores new approaches to the treatment of victims of torture, and makes clear how vital it is to address the needs of refugees individually. Our obligations to protect refugees do not end with protecting them from refoulement, but extend to enabling them to start productive new lives. The extent to which the scars of past experiences can, if not healed, impede settlement and integration is often underestimated and should be of concern to government officials and the wider community.

Despite their diversity, each of the articles in this issue highlights the need for a better understanding of migration in a globalized world, and for an open and transparent discussion of practical actions which can be taken when the interests of states clash with the protection needs of individuals. If there is a single theme which emerges from this issue, it is the need for a clear vision of how to preserve refugee protection in the face of such compelling, but often competing, challenges. The absence of direction is deeply troubling to human rights advocates the world over.

Judith Kumin is Visiting Professor at Carleton University, on leave from the Office of the UN High Commissioner for Refugees. The opinions expressed in this editorial are those of the author alone, and do not represent the views of the United Nations or of the UNHCR. 